\title{
Analisis Korepondensi Terhadap Karakteristik Kinerja Dosen Berdasarkan Faktor Penentu Mutu Pelayanan Di Jurusan Matematika Fmipa Universitas Sam Ratulangi
}

\author{
${ }^{1}$ Djaka Liputo, ${ }^{2}$ Djoni Hatidja, ${ }^{3}$ Yohanes A.R. Langi \\ ${ }^{1}$ Program Studi Matematika, FMIPA, UNSRAT, djakaliputo@yahoo.com \\ ${ }^{2}$ Program Studi Matematika, FMIPA, UNSRAT, dhatidja@gmail.com \\ ${ }^{3}$ Program Studi Matematika, FMIPA, UNSRAT, yarlangi@gmail.com
}

\begin{abstract}
Research has been conducted to determine the performance characteristics of lecturers based on determinants of service quality in the Department of Mathematics FMIPA of Sam Ratulangi University by using the correspondence analysis. The data used are primary data obtained through the distribution of questionnaires to students of academic year 2012/2013 that are 28 courses and 357 respondence. Based on the results of correspondence analysis found that five factors determining the lecturer and the service has a significant relationship. There is a relationship between the lecture and five factor determinants of service that can be seen through the results of the correspondence analysis plot. Diversity is explained by the plot of $90.71 \%$. Objects or lecturer adjacent to one variable (reliability) is a Lecturer 4, Lecturer 8, Lecturer 11 and Lecturer 14. Objects that are adjacent to the two variables (responsiveness) is Lecturer 7, Lecturer 9, Lecturer 12, Lecturer 15 and Lecturer 17. Objects adjacent to the three variables (collateral) is Lecture 2, Lecture 6, Lecture 8, Lecturer 16 and Lecturer 21. Furthermore, Lecture 1, Lecture 3, Lecture 5, Lecture 6, Lecture 15, Lecture 18, and Lecturer 20 are approaching four variables (empathy). Lecturer 3, Lecturer 5, Lecturer 9, Lecturer 12, Lecturer 15, Lecturer 17 and Lecturer 18 are objects that are close to five variables (direct evidence). This shows the closeness between the lecture and five factor determinants of service.
\end{abstract}

Keywords : Correspondence Analysis, Lecturer, Student, Service

\begin{abstract}
Abstrak
Telah dilakukan penelitian untuk mengetahui karakteristik kinerja dosen berdasarkan faktor penentu mutu pelayanan di Jurusan FMIPA UNSRAT dengan menggunakan Analisis Korespondensi. Data yang digunakan adalah data primer yang diperoleh melalu i pembagian kuesioner kepada mahasiswa tahun ajaran 2012/2013 yakni sebanyak 28 mata kuliah dan 357 jumlah responden. Berdasarkan hasil analisis korespondensi diperoleh bahwa dosen dan lima faktor penentuan pelayanan memiliki hubungan yang signifikan. Terdapat hubungan antara dosen dan lima faktor penentu pelayanan yang dapat dilihat melalui hasil plot analisis korespondensi. Keragaman yang diterangkan oleh plotnya sebesar 90,71\%. Objek-objek atau dosen yang berdekatan pada variabel satu (kehandalan) adalah Dosen 4, Dosen 8, Dosen 11, dan Dosen 14. Objek- objek yang berdekatan dengan variabel dua (daya tanggap) adalah Dosen 7, Dosen 9, Dosen 12, Dosen 15, dan Dosen 17. Objek-objek yang berdekatan dengan variabel tiga (jaminan) adalah Dosen 2, Dosen 6, Dosen 8, Dosen 16 dan Dosen 21. Selanjutnya, Dosen 1, Dosen 3, Dosen 5, Dosen 6, Dosen 15, Dosen 18, dan Dosen 20 mendekati variabel empat (empati). Dosen 3, Dosen 5, Dosen 9, Dosen 12, Dosen 15, Dosen 17, dan Dosen 18 adalah objek-objek yang mendekati variabel lima (bukti langsung). Hal ini menunjukan adanya kedekatan antara dosen dan lima faktor penentu pelayanan.
\end{abstract}

Kata kunci: Analis Korespondensi, Dosen, Mahasiswa, Pelayanan

\section{Pendahuluan}

Kinerja dosen merupakan suatu hal yang sangat penting dalam upaya lembaga perguruan tinggi untuk mencapai tujuannya. Kinerja dosen dalam proses pembelajaran merupakan jembatan transfer ilmu pengetahuan yang paling utama. Dengan kinerja yang optimal proses belajar mengajar akan tercipta dengan lancar [4].Dalam dunia yang kompetitif dan mengglobal setiap perguruan tinggi, seperti Universitas Sam Ratulangi khususnya di jurusan Matematika, memerlukan kinerja dosen yang tinggi. Salah satu cara untuk melakukan evaluasi kinerja dosen 
yaitu dengan cara pengukuran kualitas dosen menggunakan mahasiswa sebagai penilai. Data diperoleh dengan menggunakan metode Analisis Korespondens i.

Analisis korespondensi merupakan sebuah teknik multivariat secara grafik yang digunakan untuk eksplorasi data dari sebuah tabel kontingensi. Analisis korespondensi ini bertujuan untuk melihat ada tidaknya hubungan antara peubah secara visual, sekaligus dapat digunakan untuk melihat keterkaitan (kedekatan) suatu kategori pada satu peubah terhadap kategori peubah lainnya.[5].

\section{Analisis Korenspondensi}

Analisis korespondensi merupakan salah satu teknik analisis peubah banyak untuk menganalis is tabel kontingensi dua arah (tabulasi silang dari dua variabel kategori). Sedangkan tabel kontingensi merupakan tabel klasifikasi dua arah dari peubah-peubah kategori yang memuat data kategori dengan skala nominal dan ordinal yang digunakan sebagai input yang menunjukkan suatu asosiasi kualitatif antara baris dan kolom.

Data dengan skala nominal dan ordinal merupakan data yang sangat sederhana karena hanya berupa frekuensi hasil pencacahan atau enumerasi. Analisis untuk data berupa frekuensi ini sangat terbatas karena sifatnya yang hanya boleh dijumlahkan. Secara deskriptif, data berupa frekuensi untuk peubah kategori digambarkan dalam diagram batang. Secara inferensia analis is ini mengukur derajat kebebasan antara dua peubah kategori. Pengukuran kebebasan ini merupakan indeks numerik yang menggambarkan kedekatan hubungan antar dua peubah kategori tersebut. [3].

\subsection{Metode Analisis Korespondensi}

Dalam mengaplikasikan analis is data korespondensi ke dalam matrik yang datanya berupa rating dalam aturan skala tertentu, merekomendasikan penggandaan kolom dari matriks data. Dengan demikian setiap kolom akan digambarkan oleh sebuah pasangan kolom dimana setiap kolom memuat suatu nilai yang diberikan dan kolom la innya (pasangannya) memuat suatu nilai sebagai pelengkap. Setiap kolom kemudian digambarkan oleh satu pasangan nilai, "positif" dan "negatif", sehingga dapat ditemukan bahwa baris (alternatif pilihan) yang mempunyai nilai tinggi untuk kolom tertentu, apabila digambarkan, letaknya cenderung lebih dekat kepada nilai positif dari pada nilai negatif untuk kolom tersebut dan sebaliknya.

Sebagai contoh dapat ditampilkan sebuah matriks data yang berukuran $\mathbf{N} X \mathbf{P}$ dimana $\mathbf{N}$ merupakan banyaknya variabel kualitatif dalam baris dan $\mathbf{P}$ merupakan banyaknya variabel kualitatif dalam kolom, misalkan:

$\mathbf{P}+=$ Kolom dari matriks data yang mengindikasikan hasil pengukuran berasosiasi positif antara baris dan kolom.

$\mathbf{P}-\mathbf{=}$ Kolom dari matriks data yang mengidentifikasi hasil pengukuran berasosiasi negative baris dan kolom

$\mathrm{X}_{\mathrm{ij}}=$ Nilai rating untuk kolom $\mathbf{P}+$ baris ke-i kolom ke-j.

$\mathrm{I}=1,2, \ldots, \mathrm{N}$.

$\mathrm{j}=1,2, \ldots, \mathrm{P}$.

$\mathrm{t}_{\mathrm{j}}=$ Nilai rating terbesar dari variabel kolom (kriteria) ke-j.

$\mathrm{t}_{\mathrm{j}}-\mathrm{X}_{\mathrm{ij}}=$ Nilai rating untuk kolom $\mathbf{P}$ - baris ke-i kolom ke-j. [1]

\subsection{Matriks Korespondensi}

Misalkan $\mathbf{N}$ matriks kontingensi, dan $\mathbf{P}$ matriks korespondensi.

$$
\begin{aligned}
& \mathbf{N}(I \times J) \equiv\left[\mathrm{n}_{\mathrm{ij}}\right] ; \mathrm{n}_{\mathrm{ij}} \geq 0 \\
& \mathbf{P} \equiv(1 / \mathrm{n} . .) \mathbf{N} ; \mathrm{n} . .=\mathbf{1}^{\mathrm{T}} \mathbf{N} \mathbf{1}
\end{aligned}
$$

Jumlah baris dan kolom $\mathbf{P}$ ditulis sebagai 


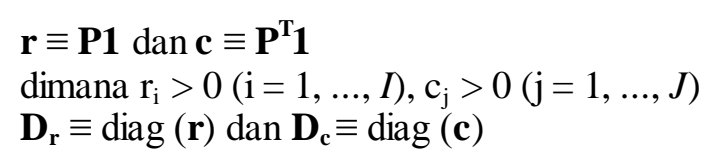

Matriks $\mathbf{P}$ disebut juga matriks kepadatan peluang, karena jika kita jumlahkan setiap baris matriks $\mathbf{P}$ hasilnya 1 (satu). Simbol 1 pada persamaan di atas adalah matriks kolom yang setiap unsurnya adalah 1 (satu), ditulis $\mathbf{1} \equiv\left[\begin{array}{lll}1 & \ldots & 1\end{array}\right]^{\mathrm{T}}$. $\mathbf{D}_{\mathbf{r}}$ dan $\mathbf{D}_{\mathbf{c}}$ berturut-turut adalah matriks diagonal baris dan matriks diagonal kolom yang unsur diagonalnya masing-masing adalah $\mathbf{r}$ dan $\mathbf{c}$ [1].

\subsection{Matriks Profil dan Kolom}

Matriks profil baris dan kolom dari $\mathbf{P}$ didefinis ikan sebagai vektor baris dan vektor kolom dari $\mathbf{P}$ dibagi oleh jumlah masing-masing, ditulis:

$$
R \equiv D_{r}{ }^{-1} P \equiv\left[\begin{array}{c}
r_{1}^{\sim T} \\
\vdots \\
r_{I}^{\sim T}
\end{array}\right] \text { dan } C \equiv D_{C}{ }^{-1} P^{T} \equiv\left[\begin{array}{c}
C_{1}^{\sim T} \\
\vdots \\
C_{J}^{\sim T}
\end{array}\right]
$$

Kedua profil baris $\tilde{\boldsymbol{r}}_{\boldsymbol{i}}(\mathrm{i}=1 \ldots I)$ dan profil kolom $\tilde{c}_{j}(\mathrm{j}=1 \ldots J)$ masing-masing ditulis $\quad$ dalam baris $\mathbf{R}$ dan kolom $\mathbf{C}$. Profil-profil ini identik dengan baris dan kolom $\mathbf{N}$ yang dibagi oleh jumlah masing-masing. Maka jarak yang digunakan untuk menggambarkan kedekatan antar profil ialah jarak Khi kuadrat, yaitu:

1. $\left(r_{i}-r_{j}\right)^{\prime} D_{c}^{-1}\left(r_{i}-r_{j}\right)$ untuk jarak antar profil kolom $\mathrm{r}_{\mathrm{i}}$ dengan profil baris $\mathrm{r}_{\mathrm{j}}$,

2. $\left(c_{i}-c_{j}\right)^{\prime} D_{r}^{-1}\left(c_{i}-c_{j}\right)$ untuk jarak antar profil baris $\mathrm{c}_{\mathrm{i}}$ dengan profil kolom $\mathrm{c}_{\mathrm{j}}$.

Profil-profil baris dan kolom di atas ingin digambarkan dengan menumpang tindihkannya dalam ruang dimensi rendah. Bila dengan PNSU (Penguraian Nilai Singular Umum) diperoleh bahwa, $P$ $r c^{\prime}=A D_{\mu} B ; A^{\prime} D_{r}^{-1} A=B^{\prime} D_{c}^{-1} B=I$ maka profil baris matriks $\mathrm{R}$ yang posisi relatifnya sama dengan profil baris matriks $\mathrm{R}-1 \mathrm{c}$ ' diberikan oleh $\mathrm{F}=\mathrm{D}_{\mathrm{r}}^{-1} \mathrm{AD}_{\mu}$. Profil kolom matriks $\mathrm{C}$ yang posisi relatifnya sama dengan profil kolom matiks $C-1 r^{\prime}$, diberikan oleh $G=D_{c}^{-1} A D_{\mu}$.

Sehingga koordinat dari profil baris dan kolom masing-masing adalah:

$\mathrm{F}=\mathrm{D}_{\mathrm{r}}^{-1} \mathrm{AD}_{\mu}$ dan $\mathrm{G}=\mathrm{D}_{\mathrm{c}}^{-1} \mathrm{AD}_{\mu}$ Kontribusi relatif digunakan untuk melihat proporsi keragaman yang dapat diterangkan oleh sumbu utama terhadap titik tersebut.[2]

\section{Metode Penelitian}

\subsection{Data}

Data yang digunakan dalam penelitian adalah data primer yakni data yang diperoleh langsung dengan membagikan kuesioner diberikan kepada mahasiswa Jurusan Matematika yang sedang mengikuti mata kuliah semester genap TA 2012/2013. Waktu pengambilan data dalam penelitian ini akan dilakukan pada bulan Mei-Juni 2013. Adapun tempat penelitiannya akan dilaksanakan di Manado Provinsi Sulawesi Utara khususnya di Fakultas MIPA UNSRAT.

Di Jurusan Matematika Fakultas MIPA UNSRAT terdapat 33 mata kuliah untuk semester genap. Kuesioner akan disebar hanya untuk 28 matakuliah karena matakuliah Praktek Kerja Lapangan, Kuliah Kerja Terpadu, Seminar dan Skripsi merupakan matakuliah yang dilaksanakan di luar kelas. Kuesioner yang disebarkan kepada mahasiswa pada setiap matakuliah semester genap mencakup penilaian terhadap satu dan dua dosen karena terdapat matakuliah yang diajarkan oleh satu atau dua dosen.

\subsection{Variabel- variabel yang di Analis is}

Peubah-peubah yang diamati adalah peubah penentu mutu pelayanan yang terdiri dari kehandalan, daya tanggap, jaminan, empati, dan bukti langsung. 


\subsection{Prosedur Penelitian}

Metode analisis yang dilakukan dalam penelitian ini terdiri dari 2 tahap. Tahapan analisis yang dilakukan adalah sebagai berikut:

1. Data asal dianalisis dengan statistika deskriptif untuk mengetahui gambaran data secara umum menggunakan software Microsoft Excel.

2. Melakukan analisis korespondensi.

Langkah-langkah untuk menyelesaikan penelitian ini adalah :

1. Pengumpulan Data

2. Pengolahan Data

a) Membuat tabel kontingensi

b) Melakukan analisis korespondensi pada tabel data (berupa tabel kontingensi) yang didapat dari Langkah a.

c) Membuat peta persepsi dengan menggunakan Analis is Korespondensi

\section{Hasil Dan Pembahasan}

\subsection{Deskripsi Peubah Berdasarkan Faktor Penentu Mutu Pelayanan}

Ada 5 faktor penentu mutu pelayanan yaitu kehandalan, daya tanggap, jaminan, empati dan bukti langsung.

\subsubsection{Deskripsi Peubah Kehandalan}

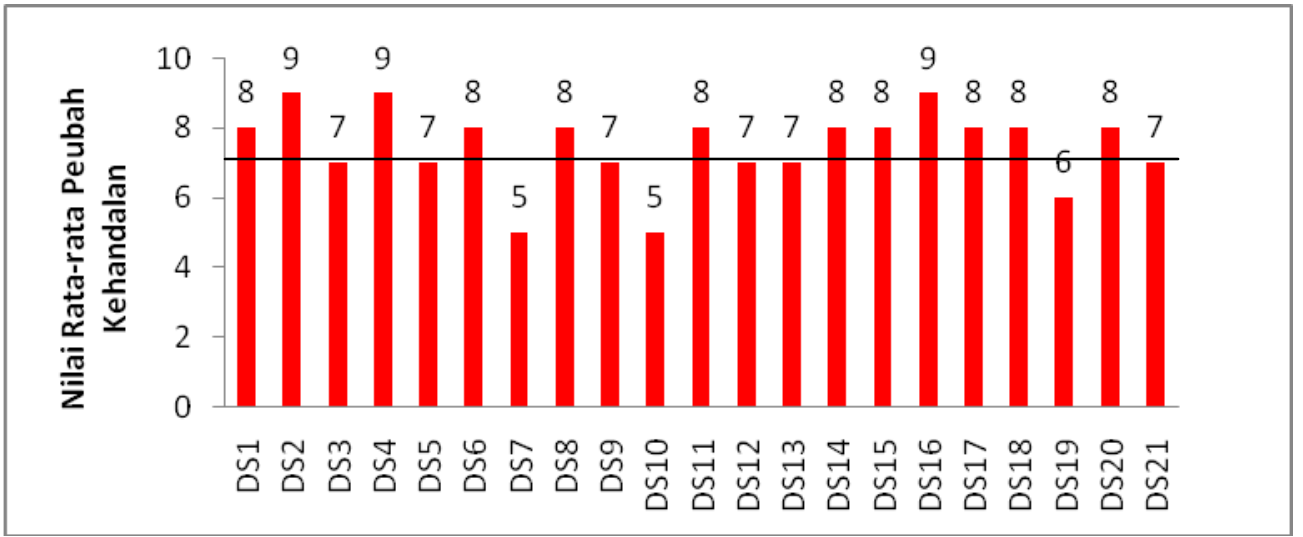

Gambar 1. Nilai Rata-Rata Peubah Kehandalan (X1F)

Berdasarkan gambar 1, nilai rata-rata peubah kehandalan tertinggi dimiliki oleh DS2, DS4, dan DS16 sebesar 9 diikuti oleh DS1, DS6, DS8, DS11, DS14, DS15, DS17, DS18, dan DS20 sebesar 8 serta DS3, DS5, DS9, DS12, dan DS21 sebesar 7. Nilai ratarata peubah kehandalan terendah dimiliki oleh DS7 dan DS10 sebesar 5. Dari gambar 1 dapat terlihat bahwa objek-objek yang memiliki nilai rata-rata lebih dari 7 adalah DS1, DS2, DS4, DS6, DS8, DS11, DS14, DS15, DS16, DS17, DS18, dan DS20. Sedangkan yang memiliki nilai rata-rata yang kurang dari 7 yaitu DS7, DS10, dan DS1. 


\subsubsection{Deskripsi Peubah Daya Tanggap}

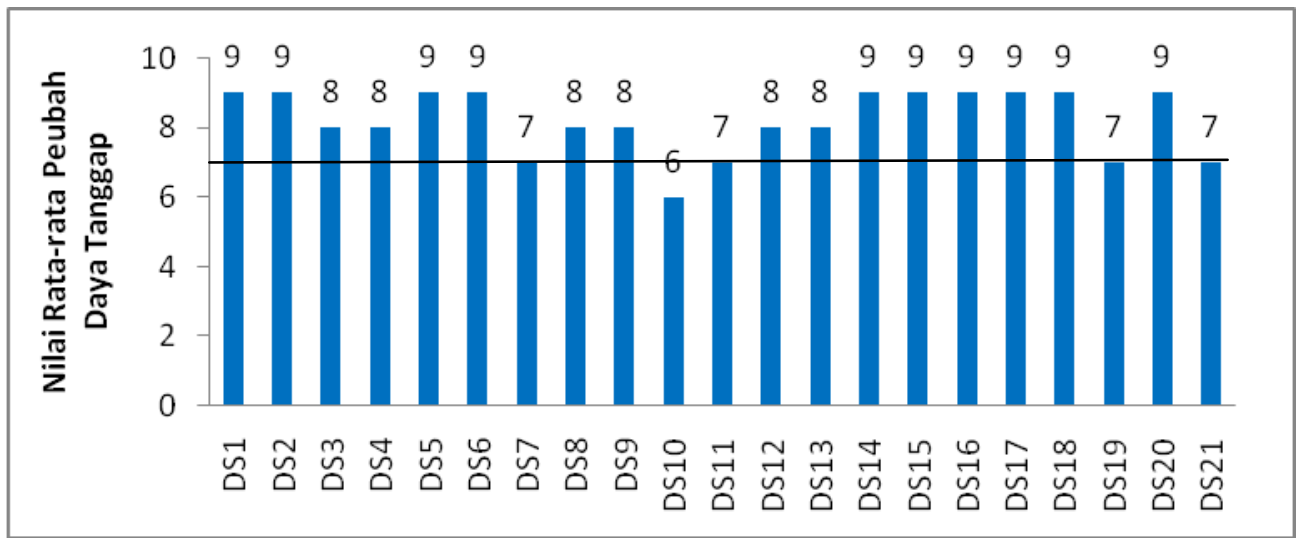

Gambar 2. Nilai Rata-Rata Peubah Daya Tanggap (X2I)

Berdasarkan gambar 2 peubah nilai rata-rata peubah daya tanggap tertinggi dimiliki oleh DS1, DS2, DS5, DS6, DS14, DS15, DS16, DS17 dan DS18 dan DS20 sebesar 9. Nilai rata-rata peubah daya tanggap terendah dimiliki oleh DS10 sebesar 6.

Dari gambar 2 dapat terlihat bahwa selain DS7, DS10, DS11, DS19 dan DS21 memiliki nilai rata-rata lebih dari 7.

\subsubsection{Deskripsi Peubah Jaminan}

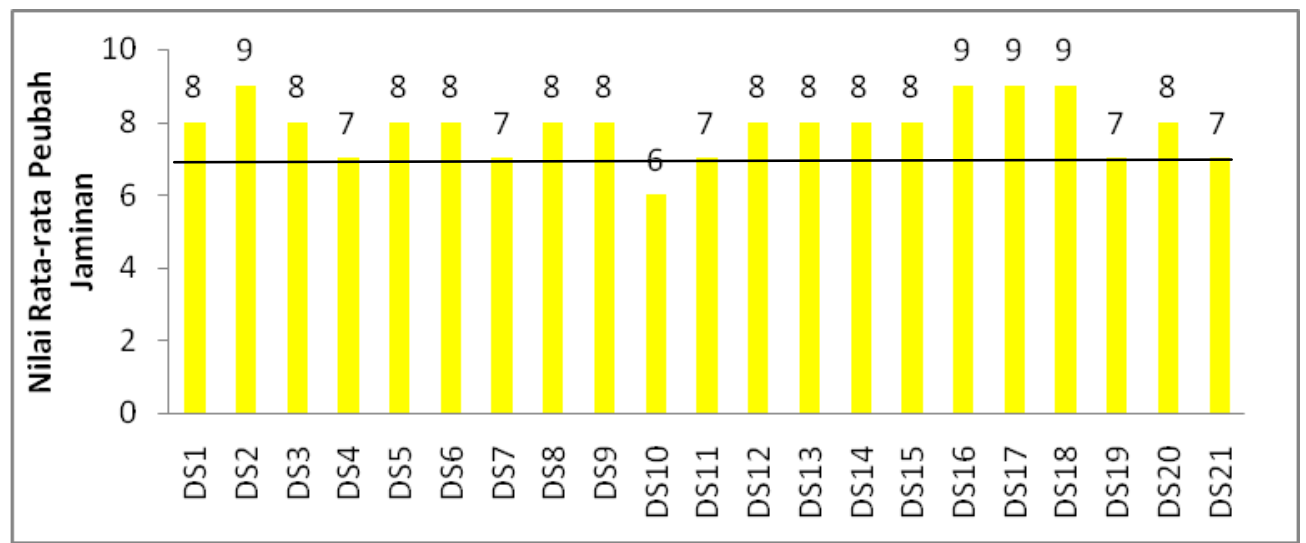

Gambar 3. Nilai Rata-rata Peubah Jaminan (X3H)

Berdasarkan gambar 3 dapat dilihat bahwa nilai rata-rata peubah jaminan tertinggi dimiliki oleh DS2, DS16, DS17, dan DS18 sebesar 9. Sedangkan nilai rata-rata peubah jaminan terendah dimiliki oleh DS10 sebesar 6. Dari gambar 3 dapat terlihat bahwa objekobjek yang memiliki nilai rata-rata lebih dari 7 adalah DS1, DS2, DS3, DS5, DS6, DS8, DS9, DS12, DS13, DS14, DS15, DS16, DS17, DS18 dan DS20. 


\subsubsection{Deskripsi Peubah Empati}

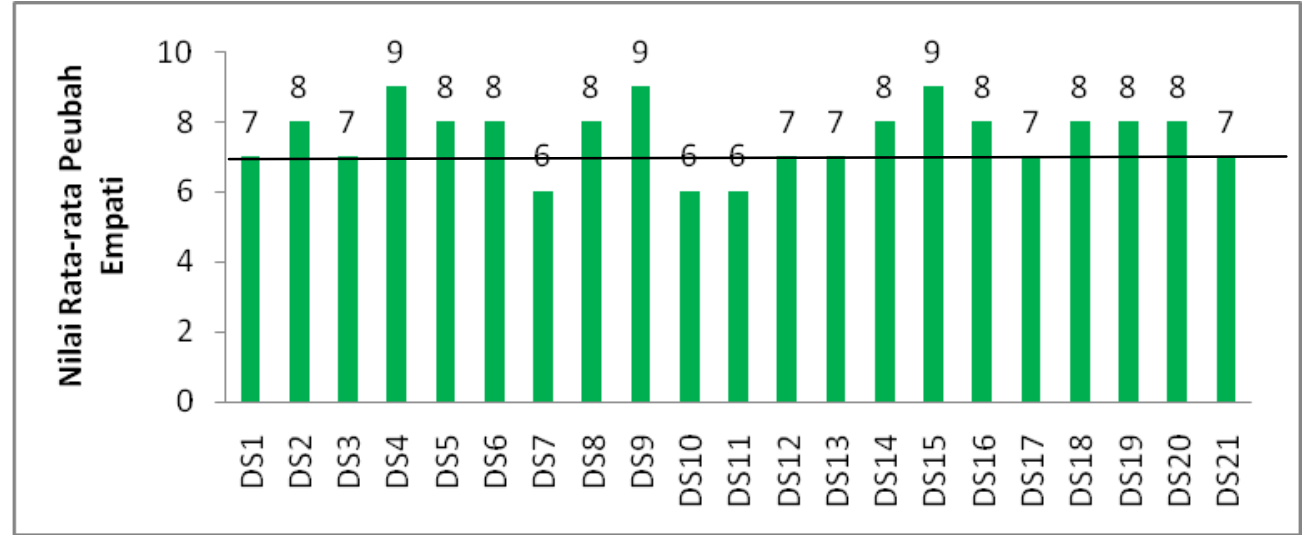

Gambar 4. Nilai Rata-Rata Peubah Empati (X4C)

Berdasarkan gambar 4 dapat dilihat bahwa nilai rata-rata peubah empati tertinggi dimiliki oleh DS4, DS9, dan DS15 sebesar 9. Sedangkan nilai rata-rata peubah empati terendah sekaligus yang kurang dari 7 dimiliki oleh DS7, DS10, dan DS11 sebesar 6. Dari gambar 4 dapat terlihat bahwa objek-objek yang memiliki nilai rata-rata lebih dari 7 adalah DS2, DS4, DS5, DS6, DS8, DS9, DS14, DS15, DS16, DS18, DS19 dan DS20.

\subsubsection{Deskripsi Peubah Bukti Langs ung}

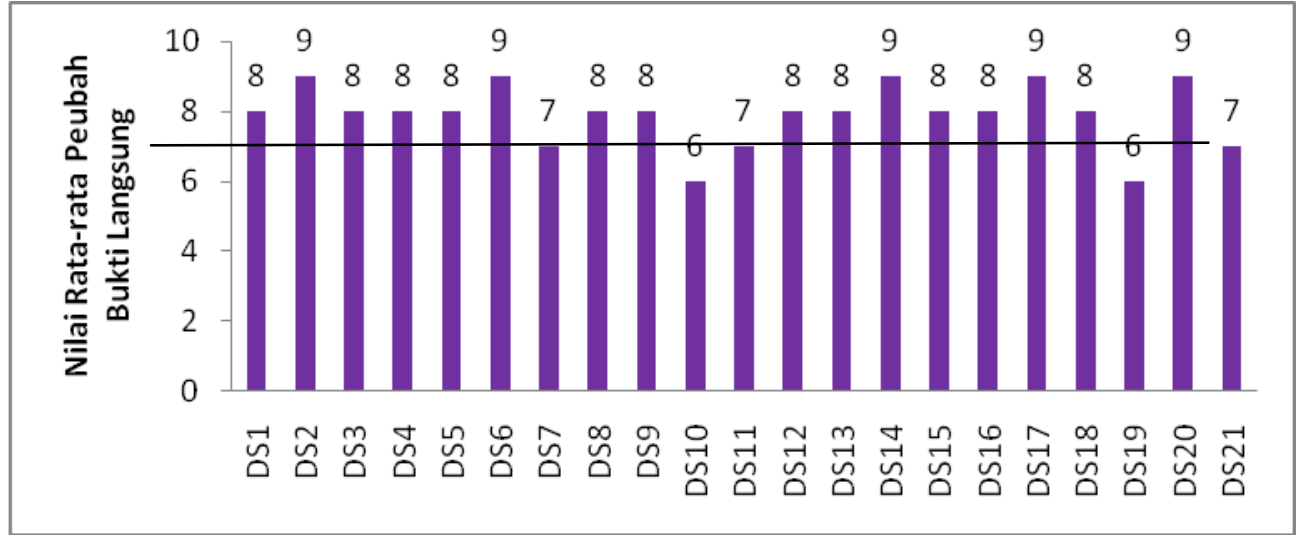

Gambar 5. Nilai Rata-rata Peubah Bukti Langsung (X5D)

Berdasarkan gambar 5 dapat dilihat bahwa nilai rata-rata peubah bukti langsung terting gi dimiliki oleh DS2, DS6, DS14, DS17 dan DS20 sebesar 9. Sedangkan nilai ratarata peubah bukti langsung terendah dimiliki oleh DS10 dan DS19 sebesar 6. Dari gambar 5 dapat terlihat bahwa objek-objek yang memiliki nilai rata-rata lebih dari 7 adalah DS1, DS2, DS3, DS4, DS5, DS6, DS8, DS9, DS12, DS13, DS14, DS15, DS16, DS17, DS18, dan DS20. Sedangkan yang memiliki nilai rata-rata yang kurang dari 7 yaitu DS10 dan DS20. 


\subsection{Plot Analisis Korespondensi}

Dengan menggunakan plot Analisis Korespondensi maka dapat ditampilkan secara simultan atau secara nyata hubungan antara kategori baris dengan kategori kolom. Plot Analisis Korespondensi dapat diamati pada gambar di bawah ini:

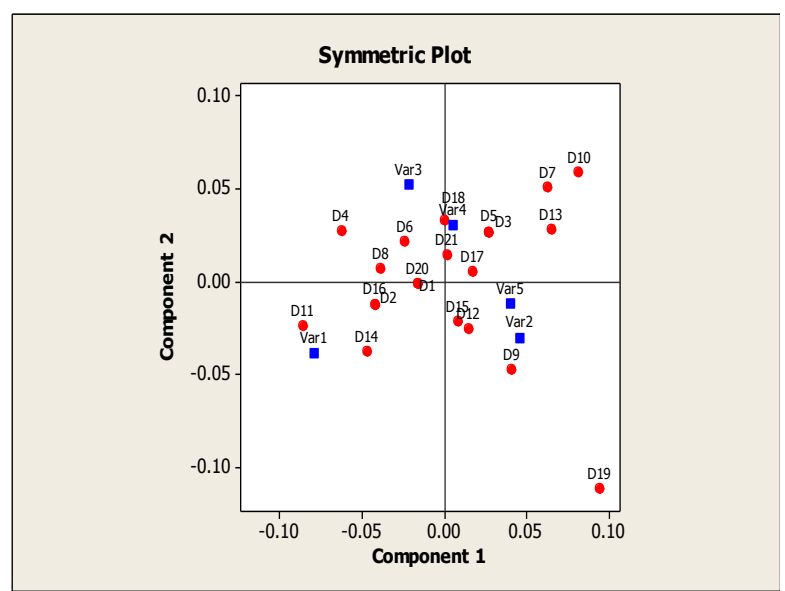

Gambar 7. Plot Analisis korespondensi (Komponen 1 dan 2)

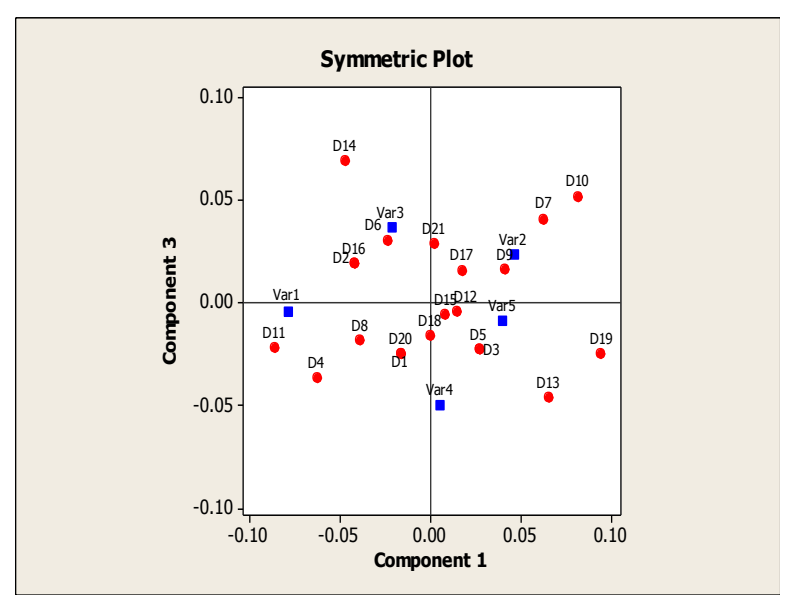

Gambar 8. Plot Analisis korespondensi (Komponen 1 dan 3)

Berdasarkan gambar 6 dan 7 dapat dijelaskan bahwa hampir keseluruhan objekobjek bedekatan. Hal ini menunjukkan bahwa karakteristik objek-objek tersebut relatif sama. Namun ada objek-objek tertentu yang berjauhan dengan objek-objek lainnya, seperti terlihat pada DS10, DS13, dan DS19. Objek tersebut berjauhan dengan objekobjek lain atau dari kelima variabel. Begitu juga kedekatan antara kategori kolom dengan kolom, telihat var2 dan var5 saling berdekatan. Sama halnya dengan Var3 dan Var 4 adanya saling berdekatan antara kedua variabel tersebut. Ini menunjukan penilaian objek terhadap vaiabel tesebut relatif sama.

\section{Kesimpulan}

Dari hasil dan pembahasan di atas dapat ditampilkan hubungan antara dosen dengan dosen lainnya dan dosen dengan lima factor penentu pelayanan secara simultan melalui hasil yang ditampilkan pada plot Analisis Korespondensi. Keragaman yang diterangkan oleh plot 1 dan 2 sebesar $90,71 \%$. Objek-objek atau dosen yang berdekatan pada variabel satu (kehandalan) adalah Dosen 4, Dosen 8, Dosen 11, dan Dosen 14. Nilai rata-rata objek-objek tersebut lebih tinggi pada variabel satu. Sedangkan pada Variabel dua (Daya Tanggap), objek- objek yang berdekatan dengan variabel tersebut adalah Dosen 7, Dosen 9, Dosen 12, Dosen 15, dan Dosen 17. Hal ini menunjukan nilai rata-rata pada objek lebih tinggi pada variabel dua .

Hasil analisis juga menunjukkan bahwa objek-objek yang berdekatan dengan variabel tiga (Jaminan) adalah Dosen 2, Dosen 6, Dosen 8, Dosen 16 dan Dosen 21. Selanjutnya, Dosen 1, Dosen 3, Dosen 5, Dosen 6, Dosen 15, Dosen 18, dan Dosen 20 mendekati variabel empat (empati). Dosen 3, Dosen 5, Dosen 9, Dosen 12, Dosen 15, Dosen 17, dan Dosen 18 adalah objekobjek yang mendekati variabel lima (Bukti Langsung). Hal ini menunjukan adanya kedekatan antara kategori baris dan kolom. Selain itu, terdapat sebagian objek atau dosen yang hanya dekat pada satu variabel. Namun ada juga objek yang jauh dari kelima variabel dapat dilihat pada Dosen7, Dosen10, dan Dosen19. Ini menunjukan bahwa dosen tersebut kurang penilaiannya terhadap kelima variabel faktor penentu pelayanan. 


\section{Daftar Pustaka}

[1] Anggraini. 2010. Analis is Korespodensi Hubungan Antara Kondisi Sekolah, Tenaga Pengajar, Dan Sarana Belajar Terhadap Prestasi Sekolah.Jurnal Penelitian Sains

[2] Goldberg, Jack.L., 1991. Matrix Theory With Apllications, McGraw-Hill Inc, New York.

[3] Hair, Jr, J.F.; Black, W.C.; Babin, B.J.; Anderson, R.E.; Tatham, R.L., 2006. Multivariate Data Analysis, 6th Ed, Pearson Education Inc, Singapore

[4] Sarjono, Wawarni, Prajitno, Darwanto. 2010. Standar Evaluasi Kinerja Dosen Sekolah Tinggi Teknologi Ronggolawe Cepu STTR Cepu, Kabupaten Blora.

[5] Putra BJ Bangun, Irmeilyana, Indriandarini, Analisis Korespondensi Untuk Mengetahui Hubungan Lama Studi Dengan IPK Dan Lama Skripsi Alumni Matematika FMIPA UNSRIT 2001-2002. Jurnal Penelitian Sains. 2011.14(1A). 